\title{
RELATIONSHIP BETWEEN COMPRESSIVE STRENGTH AND MODULUS OF ELASTICITY OF SELF CONSOLIDATING HIGH PERFORMANCE CONCRETES (SCHPCS) INCORPORATING GSA AS SCM
}

Buari T.A ${ }^{1,2,3^{*}}$ Olutoge F.A , $^{2,3}$ Ayininuola G. M. ${ }^{3}$

${ }^{1}$ Department of Building Technology, The Federal Polytechnic Ede, Nigeria

${ }^{2}$ Faculty of Engineering, The University of the West Indies, Trinidad

${ }^{3}$ Department of Civil Engineering, University of Ibadan, Nigeria

${ }^{1}$ Email: buari4ever@federalpolyede.edu.ng *(Corresponding author)

2Email: Festus.olutoge@sta.uwi.edu

${ }^{3}$ Email: gm.ayininuola@ui.edu.ng

\begin{abstract}
This experimental work evaluates the relationship between compressive strength and modulus of Elasticity of self-consolidating High performance concrete (SCHPC) containing high volume of Groundnut Shell Ash (GSA) up to 40\% substitution as SCM. A total of 210 specimens of the GSA blended SCHPCs comprising 105 cubes $(100 \times 100 \mathrm{~mm})$ and 105 cylinders $(150 \times 300 \mathrm{~mm})$ were cured in water for 7,14,28,56,92,120 and 180 days hydration periods and the compressive strength and Modulus of elasticity determined. The linear relationships were studied with regression analysis. The findings revealed that all the mixes met the Modulus of Elasticity values requirement of $18,000 \mathrm{~N} / \mathrm{mm}^{2}$ to $42,000 \mathrm{~N} / \mathrm{mm}^{2}$ and the compressive results show that three substitution levels of $0 \%, 10 \%$ and $20 \%$ attained the proposed design strength (40-130 Mpa) and also satisfied the requirement for self-consolidating and high strength concretes. In conclusion, 0\%-20\% GSA substitutions (SCHPCA0-SCHPCA20) indicated a strong linear relationship with regressions values obtained varies between 0.842 and 0.954 for the two variables. Addition of GSA as SCM has improved the mechanical properties of SCHPC and creates a strong relationship between the compressive strength and Modulus of Elasticity.
\end{abstract}

Keywords: Compressive strength, GSA, Modulus of elasticity, Regression analysis and $S C H P C$.

https://doi.org/10.47412/AKTQ7222

\section{Introduction}

The global trend field of engineering materials development in the last few decades is a modification of ordinary concrete properties with the development of self-consolidating high performance concrete (SCHPC) by exploiting the benefits of high-range water reducer (HRWR) and supplementary cementing material for producing sustainable, durable, and environmentally friendly construction materials. In this research, the residual strength performance and Modulus of Elasticity of a groundnut Shell ash blended Self-consolidating high strength concrete was investigated. Groundnut shell ash (GSA) as supplementary cementing materials in SCHPC is a new trend in research area of development of new construction and engineering materials $[1,2]$. The use of SCC/HPC in engineering and construction projects globally in recent time is because of its inherited advantages of ease of workability, self-compatibility, high strength and durability 
over ordinary concrete [2]. Apart from $\mathrm{CO}_{2}$ emissions in cement production, the use of GSA has benefits such as less cement use, reduction in concrete production costs; reduces environmental pollution and improvement of the durability properties of the concrete. Many Researches have proven that GSA blended concretes are of better strength with better elasticity and minimal water absorption's $[3,4,5]$. The use of GSA as SCM in SCHPC can greatly enhance the workability, durability and aesthetic appeal of the concrete. For this reasons, this work examined the strength performance and elasticity behaviour of SCHPC developed by incorporating GSA as SCM with precautionary measures in the design and production to prevent it vulnerability like convectional concrete of known deterioration inheritance. In this study, percentages of GSA substitutions were kept at $(0 \%, 10 \%, 20 \%, 30 \%, 40 \%)$ to produce SCHPC and characteristics performance were measured after curing in water at 7,14,28, 56,92,120 and 180 days hydration periods by determining its Compressive strength and Modulus of elasticity of the hardened concretes. The Design variables and percentage substitutions level of GSA (SCM) used for this research were based on specification guidelines in $[6,7,8]$ and similar researches carried out by $[1,2,9,10,11]$.

\section{Materials and Method}

Materials employed in this research work were; OPC/GSA as binder: river sand of $4.5 \mathrm{~mm}$ as fine aggregate: crushed stones of $12.5 \mathrm{~mm}$ as coarse aggregate, a super-plasticizers and clean water for mixing and curing medium. Groundnut shell ash (GSA) used for this research was obtained through controlled burning in an electrical furnace at temperature of $650{ }^{\circ} \mathrm{C}$ for 3 hours. An amorphous class $\mathrm{C}$ ash was obtained as classified by $[12,13]$. Consequently, the physical (sieve analysis, moisture content, specific gravity) and chemical (SEM, XRF and XRD) analysis were carried out on GSA at the Soil Mechanics Laboratory of the Department of Civil Engineering, Physic Electronics laboratory of Science laboratory Department, Federal Polytechnic, Ede Osun State and Department of Civil Engineering, University of Ibadan, Oyo state, respectively. The results of physical and chemical properties of all materials used are presented in tables 1 and 2 and Figures 1.0 respectively. All aggregates used were of control moisture contents to prevent increase in the water content in the concrete mix. Cement used as the main binder is of Dangote brand that conforms to type 1 cement as specified by [14].

Table 1.0: Physical properties of materials used

\begin{tabular}{|l|l|l|l|l|c|}
\hline Property & CA & FA & OPC & GSA & $\begin{array}{l}\text { Conplast } \\
\text { SP430MS }\end{array}$ \\
\hline size (mm) & 10.5 & 4.5 & - & - & - \\
\hline Water absorption (\%) & 0.36 & 1.12 & - & - & - \\
\hline Specific gravity & 2.63 & 2.18 & 3.08 & 1.87 & \\
\hline Fineness modulus & 6.2 & 2.18 & & & \\
\hline Colour & & & Grey & Grey & Brown \\
\hline $\begin{array}{l}\text { Passed on a 45- } \mu \mathrm{m} \\
\text { (No. 325) sieve (\%) }\end{array}$ & & & 97 & 100 & - \\
\hline $\begin{array}{l}\text { Relative Density (at } \\
\text { 20oC): }\end{array}$ & & & & & 1.190 \\
\hline pH (concentrate) & & & & & 8.5 \\
\hline
\end{tabular}

Source: Laboratory Analysis and Company Manual, 2018 


\subsection{Mix Proportions}

A designed mix to obtain the target strength of $40 \mathrm{Mpa}$ at 28 days hydration was used for the production of SCHPC cubes at water / cement ratio of 0.36. The target strength was opined based on similar research in development of high strength concrete with use of fly ash as SCM with $100 \mathrm{Mpa}$ at 28days [15].cement contents were replaced by mass of total binder at $0 \%, 10 \%, 20 \%$, $30 \%$ and $40 \%$ with An amorphous groundnut shell ash.[1, 7,11$]$ recommends between $10 \%$ to $50 \%$ replacement levels for suitable SCHPC. The mix proportions and variables of all the mixes are presented in Table 2.0 and table 3.0 below. All the designed mixes had the same binder content of $510 \mathrm{~kg} / \mathrm{m}^{3}$, the coarse aggregate at $960 \mathrm{~kg} / \mathrm{m}^{3}$ and fine aggregate at $730 \mathrm{~kg} / \mathrm{m}^{3}$ for all the mixes. Super plasticizer (HRWR) was kept at $1.8 \%$ to total binder to achieve the required fresh properties of SCHPC. The samples were designed and labeled as SCMAO-SCMA4 which contains 0\%, 10\%, $20 \%, 30 \%$ and $40 \%$ GSA replacements.

Table 2.0: design Mix of SCHPC

\begin{tabular}{|l|l|l|l|l|l|l|l|l|}
\hline $\begin{array}{l}\text { Sampl } \\
\text { es }\end{array}$ & $\begin{array}{l}\text { Cemen } \\
\mathrm{t} \\
\left(\mathrm{kg} / \mathrm{m}^{3}\right.\end{array}$ & $\begin{array}{l}\text { Water } \\
\left(\mathrm{kg} / \mathrm{m}^{3}\right. \\
)\end{array}$ & $\begin{array}{l}\text { W/C } \\
\text { Rati } \\
\mathrm{o}\end{array}$ & $\begin{array}{l}\text { GSA } \\
\left(\mathrm{kg} / \mathrm{m}^{3}\right)\end{array}$ & $\begin{array}{l}\text { GS } \\
\mathrm{A} \\
(\%)\end{array}$ & $\begin{array}{l}\text { F.A } \\
\left(\mathrm{kg} / \mathrm{m}^{3}\right. \\
)\end{array}$ & $\begin{array}{l}\text { C.A. } \\
\left(\mathrm{kg} / \mathrm{m}^{3}\right. \\
)\end{array}$ & $\begin{array}{l}(\mathrm{S} . P) \quad(\% \\
\mathrm{B})\end{array}$ \\
\hline $\begin{array}{l}\text { SCMA } \\
0\end{array}$ & 510 & 185 & 0.36 & 0 & 0 & 730 & 960 & 1.8 \\
\hline $\begin{array}{l}\text { SCMA } \\
1\end{array}$ & 459 & 185 & 0.36 & 51 & 10 & 730 & 960 & 1.8 \\
\hline $\begin{array}{l}\text { SCMA } \\
2\end{array}$ & 408 & 185 & 0.36 & 102 & 20 & 730 & 960 & 1.8 \\
\hline $\begin{array}{l}\text { SCMA } \\
3\end{array}$ & 357 & 185 & 0.36 & 153 & 30 & 730 & 960 & 1.8 \\
\hline $\begin{array}{l}\text { SCMA } \\
4\end{array}$ & 308 & 185 & 0.36 & 204 & 40 & 730 & 960 & 1.8 \\
\hline
\end{tabular}

Source: laboratory analysis and product manual, 2019

Table 3.0 Variables for concrete mixtures

\begin{tabular}{|l|l|}
\hline Variables & by weight \\
\hline W/B ratios & 0.36 by weight \\
\hline Binder content & $510 \mathrm{~kg} / \mathrm{m}^{3}$ \\
\hline GSA & $\begin{array}{l}10 \%, 20 \%, 30 \%, 40 \% \text { of binder by } \\
\text { weight }\end{array}$ \\
\hline Total air content & $3 \%$ \\
\hline HRWR dosage & $1.8 \%$ of binder by weight \\
\hline Net mixing time & 7 to 13 minutes \\
\hline Segregation ration & $15 \%$ maximum \\
\hline
\end{tabular}



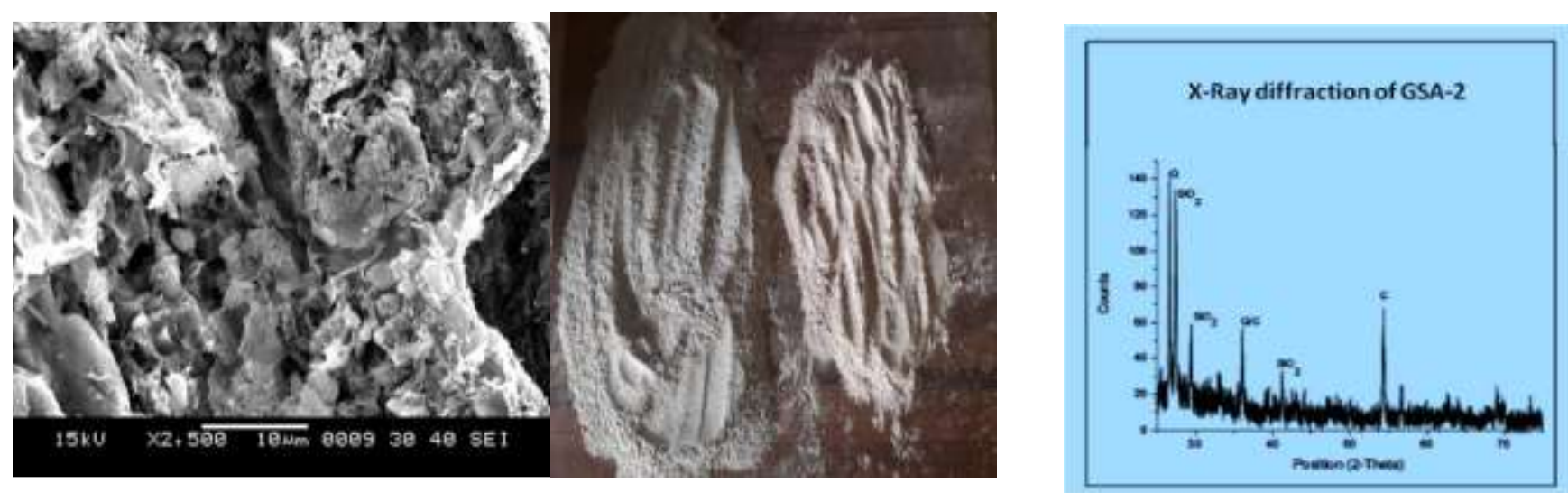

Figure1.0: SEM images (at 2500×), physical appearance of GSA resembling Portland cement and its XRD

The mineralogical and Morphological analysis of GSA were studied by using X-ray diffraction and SEM image as shown in figure 1.0 above. The SEM image revealed irregular surface with visible pores. The distinctly visible pores would enhance the pore structures formation of the concrete produced with this ash by improving the binding capacity of the component materials.

\subsection{Results Analysis and Discussions}

\subsection{Compressive Strength}

Previous researches have proved that admixtures enhance the strength and durability properties of SCHPC at later stages [16, 17]. Incorporating GSA in this research with necessary precautions has proved the importance of this admixture with increase in compressive strength of the mixes as curing age increased up to $20 \%$ replacement and this is in accordance with [2]. Generally, strength development of the mixes increased and target strength obtained at $20 \%$ substitution level compared with control. These results are similar with those obtained by [18, 19, 20], with use of fly ash, GSA and several admixtures within the values specified by[21]for high strength concrete.

Table 4.0: Compressive Strengths of SCHPCs in Water

\begin{tabular}{llllllllll}
\hline Samples & Mix & \multicolumn{7}{c}{ Compressive Strength In $\left(\mathrm{N} / \mathrm{mm}^{2}\right)$} & \\
& & 7 & 14 & 28 & 56 & 92 & 120 & 180 \\
SCMA0 & OPC only & 14.3 & 28.46 & 42.3 & 55.11 & 76.19 & 84.87 & 109.23 \\
& & 9 & & 8 & & & & \\
SCMA1 & OPC+10\% & 18.6 & 34.26 & 48.6 & 53.74 & 72.18 & 81.43 & 118.27 \\
& GSA & 0 & & 0 & & & & \\
SCMA2 & OPC +20\% & 14.1 & 17.14 & 39.8 & 59.43 & 77.92 & 85.96 & 113.92 \\
& GSA & 1 & & 3 & & & & \\
SCMA3 & OPC +30\% & 10.3 & 14.79 & 36.4 & 55.16 & 78.60 & 88.57 & 124.00 \\
& GSA & 9 & & 4 & & & & \\
SCMA4 & OPC +40\% & 9.8 & 14.00 & 33.3 & 54.00 & 83.10 & 89.75 & 118.20 \\
& GSA & & & 9 & & & & \\
\hline
\end{tabular}




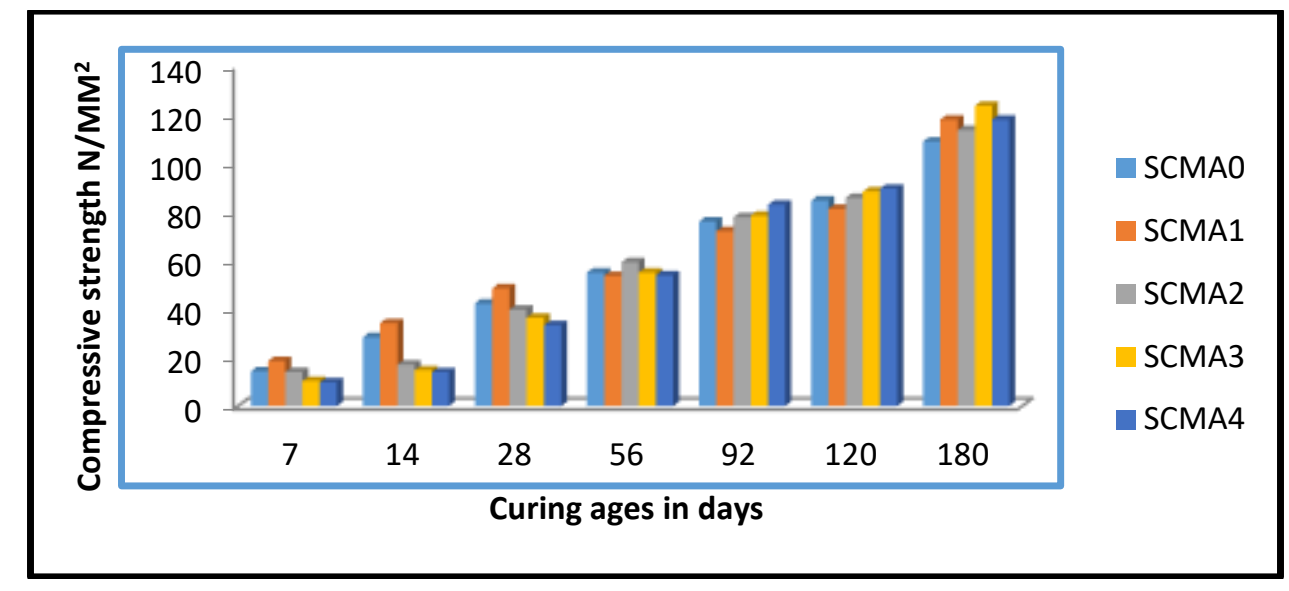

Figure 2.0: Compressive strengths of SCHPC's in water at different curing ages

Table 4.0 and figure 2.0 above presents an average compressive strength of SCHPC for various hydration periods of $7,14,28,90,120$ and 180 days with percentage substitution level of cement with GSA $(0 \%, 10 \%, 20 \%, 30 \%$ and $40 \%)$ and its strength developments variations at these curing ages of the study. The obtained results revealed gradual increase in compressive strength. At early curing age and up to $20 \%$ substitution with values of $14.39 \mathrm{~N} / \mathrm{mm}^{2}, 18.60 \mathrm{~N} / \mathrm{mm}^{2}, 14.11 \mathrm{~N} / \mathrm{mm}^{2}$, $10.39 \mathrm{~N} / \mathrm{mm}^{2}$ and $9.80 \mathrm{~N} / \mathrm{mm}^{2}$ for $0 \%, 10 \%, 20 \%, 30 \%$ and $40 \%$ GSA substitution levels respectively. The observed results was lower than values obtained by [19] with $26.13 \mathrm{~N} / \mathrm{mm}^{2}$ $, 36.34 \mathrm{~N} / \mathrm{mm}^{2}, 30.37 \mathrm{~N} / \mathrm{mm}^{2}$ and $25.43 \mathrm{~N} / \mathrm{mm}^{2}$ for $0 \%, 5 \%, 10 \%$ and $15 \%$ GSA substitution levels respectively. The behavioural pattern may be associated to the effect of GSA in reducing the reacting power of cement in the early strength development of SCHPC. However, at 28, 56, 90, 120 and 180 days, there were faster strength improvements in all GSA blended SCHPC than those control specimens $(0 \%)$. The results as shown in Table 4.0 revealed that three substitution levels of $0 \%, 10 \%$ and $20 \%$ attained the proposed design strength (40-130 Mpa) in this SCHPC designed. The obtained values satisfied the requirement for self-consolidating and high strength concretes, strength development as obtained in similar researches by $[9,10,22]$ with compressive strengths of $31.54 \mathrm{~N} / \mathrm{mm}^{2}, 36.74 \mathrm{~N} / \mathrm{mm}^{2}$ and $41.52 \mathrm{~N} / \mathrm{mm}^{2}$ respectively. The flow value, V-funnel values and U-box values of these researchers was within the stipulated values of [7].However, the rate of strength development from 7days hydration periods and 28days hydration periods was higher than 30-75\% increment obtained [9] with use of POFA and FLY ASH as their SCMs. These obtained compressive strength values reveals the suitability of GSA as SCM in developing SCHPC. In conclusion, the strength progression shows the superiority of SCHPC containing GSA over control specimen and values obtained are similar to that of [22] which recorded values of $31.22 \mathrm{~N} / \mathrm{mm}^{2}, 29.00 \mathrm{~N} / \mathrm{mm}^{2}, 27.60 \mathrm{~N} / \mathrm{mm}^{2}, 25.70 \mathrm{~N} / \mathrm{mm}^{2}$ and $21.80 \mathrm{~N} / \mathrm{mm}^{2}$ for $0 \%, 10 \%, 20 \%$, $30 \%$ and $40 \%$ recycled coarse aggregate content at 28 days in producing a self-compacting concrete and that of [19] which recorded values of $32.90 \mathrm{~N} / \mathrm{mm}^{2}, 37.21 \mathrm{~N} / \mathrm{mm}^{2}, 34.07 \mathrm{~N} / \mathrm{mm}^{2}$ and $33.57 \mathrm{~N} / \mathrm{mm}^{2}$ for $0 \%, 5 \%, 10 \%$ and $15 \%$ GSA content respectively at 28 days curing age.

\subsection{Modulus of Elasticity}

The static modulus of elasticity of concrete usually affected with the use of pozzolans (GSA) as SCM.[23], reported the effects of Pozzolans and similarities of values of modulus of elasticity of convectional and Self compacting concretes. Table 5.0 below indicated that control specimen 
( $0 \%$ GSA), has a greater values of the static modulus of Elasticity at early curing ages than those of the blended SCHPC. At 7 days, the values were $24451 \mathrm{~N} / \mathrm{mm}^{2}, 24210 \mathrm{~N} / \mathrm{mm}^{2}, 23568 \mathrm{~N} / \mathrm{mm}^{2}$, $23310 \mathrm{~N} / \mathrm{mm}^{2}$ and $20144 \mathrm{~N} / \mathrm{mm}^{2}$ for $0 \%, 10 \%, 20 \%, 30 \%$ and $40 \%$ GSA replacement of cement respectively. At 28 days, all the mixes met the requirement of $18,000 \mathrm{~N} / \mathrm{mm}^{2}$ to $30,000 \mathrm{~N} / \mathrm{mm}^{2}$ stipulated by [6] and that of $14,000 \mathrm{~N} / \mathrm{mm}^{2}$ to $42,000 \mathrm{~N} / \mathrm{mm}^{2}$ reported by [23]. For instance, the values were observed to increase at $9.89 \%, 4.75 \%, 10.30 \%, 9.40 \%$ and $4.60 \%$ for $0,10,20,30$ and 40\%GSA substitution levels respectively. At 120 and 180 days, there was no significant difference between the values obtained for the control specimen and that of $10 \%$ and 20\% GSA replacement with maximum strength increment of $4.24 \%$ attained at $20 \%$ GSA replacement in 120days hydration period. The increased in the value with curing age, particularly with 0 $20 \%$ GSA content, indicated the fact that there is a continuous hydration and pozzolanic reactions. The reduction in elasticity with increase in GSA content could be attributed to higher carbon content (expressed as loss on ignition) and low quantity of cement in the mixes as a result of its replacement. This finding is in line with the result observed by [25] that static modulus of elasticity in compression of concrete mixed with different proportions of rice husk ash and tested at 28 and 90 days period revealed that after 90 days, mixtures containing 15\% RHA showed 7\% increase in static modulus of elasticity compared to the control concrete. They concluded that generally, concrete containing RHA had higher values when compared to the control concrete. On the other hand, [26] reported that the replacement of Portland cement by slag in concrete seems to decrease the modulus of elasticity for a compressive strength below about $55 \mathrm{~N} / \mathrm{mm}^{2}$ and to increase it slightly, by about $10 \%$, for compressive strength greater than about $60 \mathrm{~N} / \mathrm{mm}^{2}$. Modulus of elasticity is reported to be low at early ages and high at later ages for fly ash-blended cement concrete [27].

Table 5.0: Summary of static modulus of elasticity of GSA blended SCHPC at different curing ages

\begin{tabular}{llllllll}
\hline SAMPLES & \multicolumn{7}{c}{ Static Modulus of Elasticity $\left(\mathrm{N} / \mathrm{mm}^{2}\right)$} \\
& $\begin{array}{l}7 \\
\text { days }\end{array}$ & 14 days & $\begin{array}{l}28 \\
\text { days }\end{array}$ & 56 days & $\begin{array}{l}92 \\
\text { days }\end{array}$ & $\begin{array}{l}120 \\
\text { days }\end{array}$ & $\begin{array}{l}180 \\
\text { days }\end{array}$ \\
\hline SCMA0 & 24451 & 27148 & 28537 & 28730 & 29034 & 30813 & 31556 \\
SCMA1 & 24210 & 25431 & 26790 & 27862 & 31875 & 32043 & 32189 \\
SCMA2 & 23568 & 23957 & 26417 & 28892 & 31154 & 32119 & 29460 \\
SCMA3 & 23310 & 23359 & 25556 & 26986 & 28981 & 30482 & 23387 \\
SCMA4 & 20144 & 22038 & 23059 & 25797 & 25863 & 21678 & 21183 \\
\hline
\end{tabular}




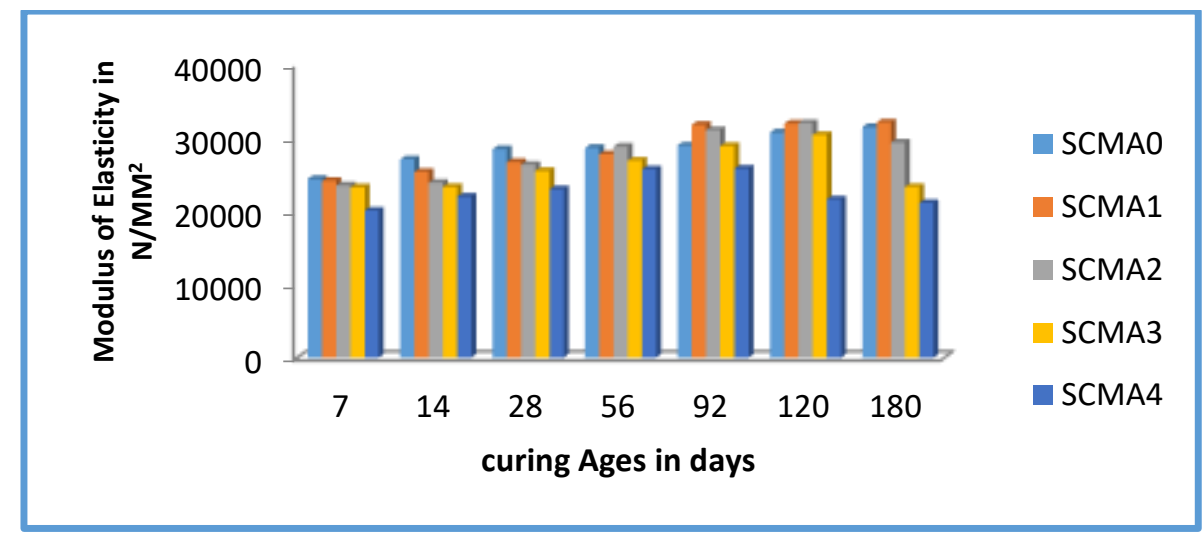

Fig.3.0: Effect of curing age on static modulus of elasticity of GSA blended SCHPC

\subsection{Relationship between Compressive Strength and Static Modulus of Elasticity}

An empirical relationship was established through mathematical regression analysis between the compressive strength and static modulus of elasticity of SCHPC incorporating different percentages of groundnut shell ash as SCM at various hydration periods $(7,14,28,56,92,120$ and 180). The summary of detailed analysis is presented in Table 6.0 with cube root of the Compressive strengths obtained at various substitutions levels, Elastic Modulus values and Compressive strengths inclusive in the table. The results revealed a higher rate of increase in Modulus of elasticity as compressive strength of samples (SCHPCA0- SCHPCA40) increases. The observed results are similar to similar researches carried out by [28, 24, 29] in both self-compacting and ordinary concretes with strength relations attributed to the beneficial effect of improvement in the density of the interfacial transition zone, as a result of slow chemical interaction between the alkaline cement paste and aggregate, which is more pronounced for the stress - strain relationship than for the compressive strength of concrete. However, there are contradictory researches as regard modulus of Elasticity of an SCC with [30,31] concluded that Modulus of Elasticity of SCC is lower than that of convectional concrete. [32] Associated contradictory of modulus of elasticity values between convectional concretes and SCC to the variations in materials components and rheological behaviour of SCC.

Table 6.0: Summary of relationship between compressive strengths and static modulus of elasticity of SCHPC incorporating GSA

\begin{tabular}{|c|c|c|c|c|}
\hline $\begin{array}{c}\text { GSA } \\
\begin{array}{c}\text { Content } \\
(\%)\end{array}\end{array}$ & $\begin{array}{c}\text { Curing } \\
\text { Age } \\
(\text { Days })\end{array}$ & $\begin{array}{c}\text { Static } \\
\text { Modulus } \\
\text { of } \\
\text { Elasticity } \\
\text { (Gpa) }\end{array}$ & $\begin{array}{c}\text { Compressive } \\
\text { Strength } \\
\left(\mathrm{N} / \mathrm{mm}^{2}\right)\end{array}$ & $\begin{array}{c}\text { Cube Root } \\
\text { of } \\
\text { Compressive } \\
\text { Strength } \\
\left(\mathrm{N} / \mathrm{mm}^{2}\right)\end{array}$ \\
\hline 0 & 7 & 24.451 & 14.39 & 2.43 \\
10 & & 24.210 & 18.60 & 2.65 \\
20 & & 23.568 & 14.11 & 2.42 \\
30 & & 23.310 & 10.39 & 2.18 \\
40 & & 20.144 & 9.80 & 2.14 \\
\hline 0 & 14 & 27.148 & 28.46 & 3.05 \\
\hline
\end{tabular}




\begin{tabular}{|c|c|c|c|c|}
\hline 10 & & 25.431 & 34.26 & 3.25 \\
20 & & 23.957 & 17.14 & 2.58 \\
30 & & 23.359 & 14.79 & 2.45 \\
40 & & 22.038 & 14.00 & 2.41 \\
\hline 0 & 28 & 28.537 & 42.38 & 3.49 \\
10 & & 26.790 & 48.60 & 3.65 \\
20 & & 26.417 & 39.83 & 3.42 \\
30 & & 25.556 & 36.44 & 3.32 \\
40 & & 23.059 & 33.39 & 3.22 \\
\hline 0 & 56 & 28.730 & 55.11 & 3.81 \\
10 & & 27.862 & 53.74 & 3.77 \\
20 & & 28.892 & 59.43 & 3.90 \\
30 & & 26.986 & 55.16 & 3.81 \\
40 & & 25.797 & 54.00 & 3.78 \\
\hline 0 & 92 & 29.034 & 76.19 & 4.24 \\
10 & & 31.875 & 72.18 & 4.16 \\
20 & & 31.154 & 77.92 & 4.27 \\
30 & & 28.981 & 78.60 & 4.28 \\
40 & & 25.863 & 83.10 & 4.36 \\
\hline 0 & 120 & 30.813 & 84.87 & 4.39 \\
10 & & 32.043 & 81.43 & 4.33 \\
20 & & 32.119 & 85.96 & 4.41 \\
30 & & 30.482 & 88.57 & 4.46 \\
40 & & 21.678 & 89.57 & 4.47 \\
\hline 0 & 180 & 31.556 & 109.23 & 4.78 \\
10 & & 32.189 & 118.27 & 4.91 \\
20 & & 29.460 & 113.92 & 4.85 \\
30 & & 23.387 & 124.00 & 4.99 \\
40 & & 21.183 & 118.20 & 4.91 \\
\hline
\end{tabular}

The Modulus of elasticity of SCHPC is calculated based on materials components used in its productions. There are no specific approach meant for SCHPC and The expression, $\mathrm{E}=9.1 \mathrm{~F}_{\mathrm{cu}}{ }^{0.33}$ proposed by [1] was applied for determination of Modulus of elasticity of SCHPC produced for this research. The results are presented in Figures 4.0 to 6.0 with regression analysis showing the various linear relationship. The regression equations below were generated for various SCHPCS produced:

SCHPCA0: $E_{s}=2.7883 F_{\mathrm{cu}}{ }^{0.33}+18.177 ;\left(R^{2}=0.9409\right)$

(1)

SCHPCA10: $\mathrm{E}_{\mathrm{s}}=4.2777 \mathrm{~F}_{\mathrm{cu}}{ }^{0.33}+12.300 ;\left(\mathrm{R}^{2}=0.8774\right)$

(2)

SCHPCA20: $E_{\mathrm{s}}=3.3359 \mathrm{Fu}^{0.33}+15.619 ;\left(\mathrm{R}^{2}=0.841\right)$

(3)

SCHPCA30: $\mathrm{E}_{\mathrm{s}}=1.4332 \mathrm{~F}_{\mathrm{cu}}{ }^{0.33}+20.79 ;\left(\mathrm{R}^{2}=0.2642\right)$

(4) 
SCHPCA40: $E_{\mathrm{s}}=0.658 \mathrm{~F}_{\mathrm{cu}}{ }^{0.33}+20.446\left(\mathrm{R}^{2}=0.098\right)$

(5)

The regression equations above revealed that Elasticity of the SCHPC produced was decreasing with the increase in the percentage substitution of groundnut shell ash. There is no significant difference between generated expressions and that of [1] for normal-weight concrete. The linear regressions values of SCHPCs obtained varies between 0.842 and 0.954 for 0\%-20\% GSA substitutions (SCHPCA0-SCHPCA20), indicating a strong linear relationship between the two variables at these levels. A static modulus of elasticity of SCHPCs at any age up to $20 \%$ substitution level can be predicted by the model given by [1] for normal weight concrete.

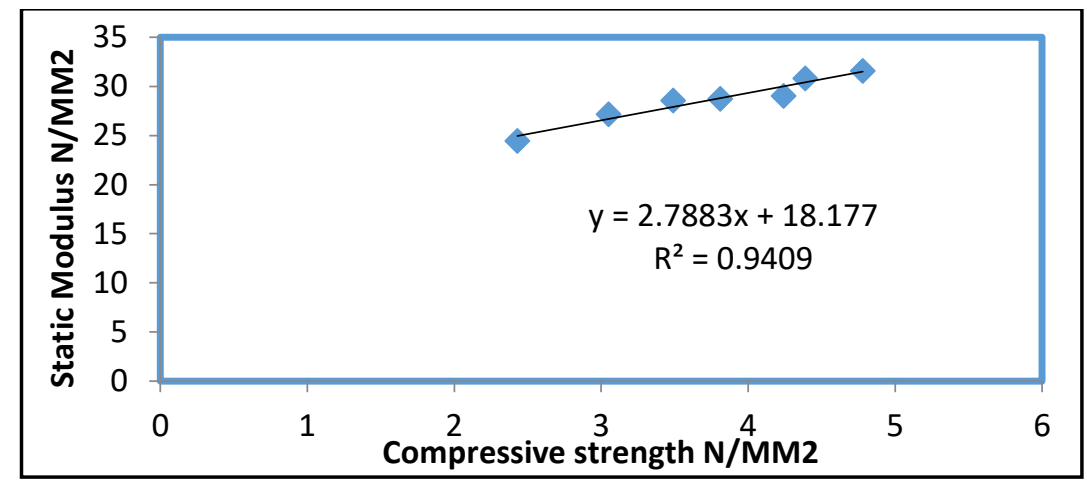

Figure 4.0: Relationship between static modulus of elasticity and compressive strength of SCHPC at $0 \%$ GSA content
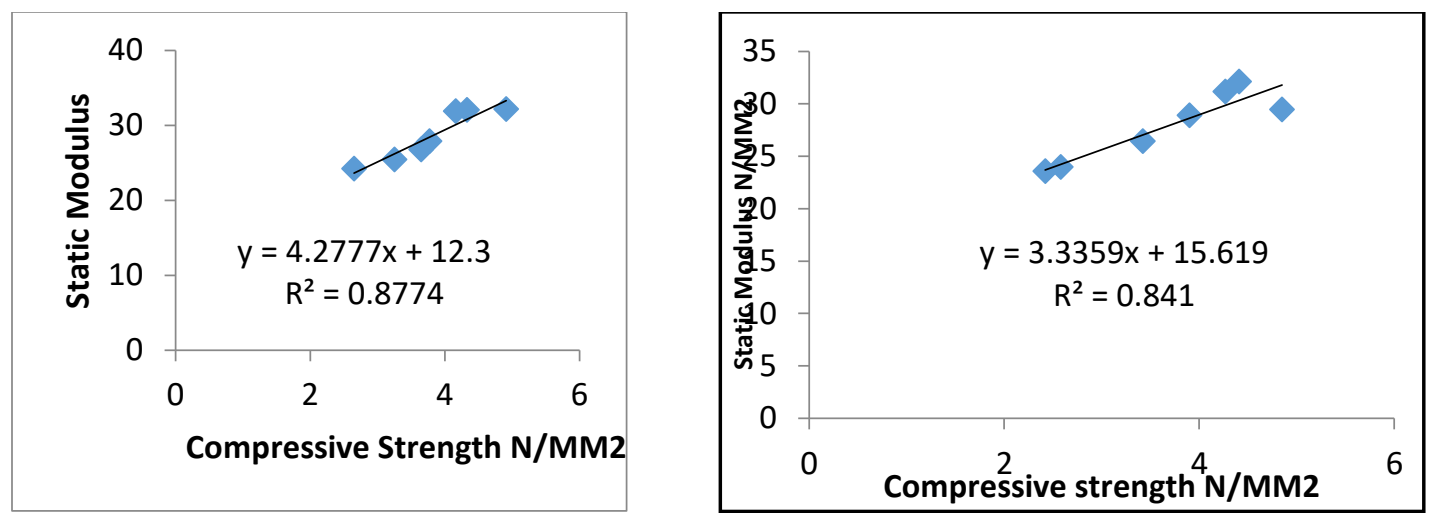

Figure 5.0: Relationship between static modulus of elasticity and compressive strength of SCHPC at $10 \%$ and $20 \%$ GSA contents respectively 


\subsection{Conclusions}

This research work has revealed the importance of admixtures (GSA) on the properties of SCHPC as both compressive strength and modulus of elasticity properties greatly depend on characteristics of cement, cementitious material, aggregates and curing ages.

The compressive strength of GSA blended SCHPC is higher than the control with a continuous strength development comparable with that of the control. The optimum level of GSA replacement from structural load view point is $10 \%$ at curing age of 28days (having attained $122.50 \%$ of the design strength).

The relationship between compressive strength and static modulus of elasticity of GSA blended SCHPC up to 180 days fitted into the model given by BS 8110-2:1985 for normal-weight concrete. Static modulus of elasticity of SCHPC has been affected by the amount of GSA substitutions in the mix and the hydration periods of the specimen.

The characteristics strength and static modulus of elasticity values of the developed SCHPC at up to $20 \%$ replacement level performed better and is suitable for production of SCHPC in an environment where high strength, durability and ease of work are required.

\section{Acknowledgement}

We acknowledge the contribution of Department of Civil Engineering of The University of Ibadan, Nigeria towards the conduct of this research. I also acknowledge The Federal Polytechnic, Ede Osun State Nigeria for sponsorship and granting of permission to use the Institution laboratories for this research. 


\section{References}

[1] BelalAlsubari, PayamShafigh and MohdZaminJumaat 2015. Development of SelfConsolidating High Strength ConcreteIncorporating Treated Palm Oil Fuel Ash. open access journal (ww.mdpi.com/journal/materials).

[2] Buari T.A, Ayininuola G. M., Agbede O. A. and Esan M.T. 2019. Effects of varying Recycled Glass and Groundnut Shell Ash on Strength and durability Properties of Self Consolidating High Performance Concretes (SCHPC). In International Research Journal of Engineering and Technology (IRJET) .Volume: 06 Issue: 03 | Mar 2019 www.irjet.net p-ISSN: 2395-0072 e-ISSN: 2395-0056.

[3] T. A. Buari, F. A. Olutoge, G. M. Ayininuola, O. M. Okeyinka, J. S. Adeleke 2019. Short term durability study of groundnut shell ash blended self-consolidating high-performance concrete in sulphate and acid environments. In Asian Journal of Civil Engineering, Springer Nature Switzerland AG 2019. (https://doi.org/10.1007/s42107-019-00131-3).

[4] Olutoge F.A, Buari T.A and Adeleke J.S 2013.Characteristics Strength and Durability of Groundnut Shell Ash (GSA) Blended Cement Concrete in Sulphate Environment. In International Journal of Scientific Engineering Research (IJSER) volume4, issue7.

[5] Naik, T.R., Kumar, R.,Ramme, B.W. and Canpolat, F.2012. Development of high-strength, economical self-consolidating concrete. Constr. Build. Material. pp 463-469.

[6] British Standard Institution 1985.Structural use of Concrete part 2: Code of Practice for Special Circumstances. BS 8110: Part 2, London, British Standard Institution.

[7] EFNARC 2002. Specification and Guidelines for Self-Consolidating Concrete.

[8] EFNARC 2005.The European Guidelines for Self-Compacting Concrete: Specification, Production and Use.

[9]Paratibha A., Rafat S., Yogesh A. and Surinder M.G. 2008. Self compacting concrete-Procedure for Mix Design. In Leonardo Electronic Journal of practices and Technologies. Issue 12,p 1524.(ISSN:1583-1078).

[10] Okamura, H.and Ozawa, K. 1995.Mix Design for Self- Compacting Concrete. Concrete Library of JSCE No. 25, (Translation of Proceedings of JSCE, No. 496/V-24, 1994.8), Tokyo, June 1995, pages 107 to 120 .

[11] Ademola S.A, Buari T.A, and Ayegbokiki S.T 2013.Characteristics Strength of groundnut shell ash (GSA) and Ordinary Portland cement (OPC) blended Concrete in Nigeria. In International Organization of Scientific Research (IOSR) Volume 3, Issue 7, july-2013.

[12] ASTM-C618 1997. American Society for Testing and Materials Standard Specification forCoal Fly Ash and Raw or Calcined Natural Pozzolan for Use in Concrete ASTM-C618. In annual Book ASTM Stand. 04.02 (1997) 294-296.

[13] ASTM C311-05 2006. Standard test methods for sampling and testing of fly ash or natural pozzolan for use in Portland-cement concrete; In Annual Book of ASTM Standard 2006; ASTM International: West Conshohocken, PA, USA, 2006; Volume 4.2; pp. 207-215.

[14] British Standards Institution 1978. B.S. 12: Ordinary and rapid hardening Portland cement (Metric Edition). British Standards Institution, London.

[15] Bouzoubaa, N., and Lachemi, M. 2001.Self-compacting concrete incorporating high volumes of class fly ash. Preliminary results," Vol. 31, Cement and Concrete Research, Pergamon- Elsevier Science, Oxford, 2001, pages 413 to 420.

[16] Hassan KE, Cabrera JG, Maliehe RS. 2000. The Effect of Mineral Admixtures on the Properties of High-Performance Concrete. Cement and Concrete Composites, v. 22, n.4, 2000; p. 267-271. 
[17] Safiuddin, M. West J., Soudki, K. 2008. Durability performance of self-consolidating concrete. In Journal of Applied Science Research, Vol 4, 1834-1840.

[18] Omar A., Rainer H., Willy M. and Irina M. 2018. The influence of variation in cement characteristics on workability and strength of SCC with fly ash and slag additions . In Construction and Building Materials 160 (2018) 258-267.

[19] Rathod S.U. and Dr.S.H.Mahure 2016. Study of Effects of Groundnut Shell Ash (GSA) on Fresh and Hardened Properties of Self Compacting Concrete. In International Journal for Scientific Research \& Development| Vol. 4, Issue 06, 2016.

[20] Tachitana, D.; Imai, M.; Yamazaki, N.; Kawai, T.; and Inada,Y. 2015. High Strength Concrete Incorporating Several Admixtures. Proceedings of the $2^{\text {nd }}$ International Symposium on High Strength Concrete, SP-121, American Concrete Institute,Farmington Hills, Michigan.

[21]American Society for Testing and Materials 1993. Test for Compressive Strength Cube and Cylidrical Concrete Specimens. ASTMC39.

[22]Panda K.C.and Bal P.K. 2013. Properties of Self compacting concrete using Recycled coarse aggregate. In International Conference on Chemical,Civil and MechanicalEngineering(NUICONE2012).

(www.Elsevier.com)https://www.sciencedirect.com/Doi:10.1016/j.proeng.2013.01.023.

[23] Bart Craeye, Petravan I., Pieter D., Veerle B. and Geert D.S. 2014. Modulus of elasticity and tensile strength of self-compacting concrete: Survey of experimental data and structural design codes. Cement and Concrete Composites Volume 54, November 2014, Pages 53-61.

[24] Oymael, S. and Durmus, A. 2006. Effects of Sulphates on Elastic Modulus of Concrete Samples Made from Blends of Cement with Oil Shale Ash, Oil Shale_vol. 21 (2), pp.125 - 134.

[25] Ramezanianpour, A. A., Khani, M. M. and Ahmadibeni, G. 2009. The Effect of Rice Husk Ash on Mechanical Properties and Durability of Sustainable Concrete. In International journal of Civil Engineering. Vol 7 (2), pp. 83 - 91.

[26] Wainwright, P. J. and Tolloczko, J. J. 1986. The Early and Later age properties of temperature OPC concrete". Second International Conference on the use of fly ash, silica fume, slag and natural Pozzolans in concrete. April, Madrib, CANMET, Ottawa, vol. 2, pp. 1293 - 1321.

[27] Bhanumathidas, N., Kalidas, N. and Inswareb, V. 2005. Sustainable development through use of fly Ash. A keynote paper presented at National Seminar on Building Materials and Technology for Sustainable Development, Ahmadabab, January.

[28] Khaleel, O. R., Al-Mishhadani, S. A., \& Razak, H. A. 2011. The effect of coarse aggregate on fresh and hardened properties of selfcompacting concrete (SCC). Procedia Engineering, Vol14, 805-813.

[29] Mehta, P. K.and Monteiro, P. J. M. 2006. Concrete: microstructure, properties, and materials $3^{\text {rd }}$ ed. New Delhi, McGraw-Hill publishing company Ltd., 659pp.

[30]Persson, B. 2001. A comparison between mechanical properties of self-compacting concrete and the corresponding properties of normal concrete. In Cement and Concrete Research, Vol.31, No.2, pp.193-198.

[31] Dinakar,Pasla, Babu K.G and Santhanam. 2008. Mechanical properties of High Volume fly ash self- compacting mixtures. Structural Concrete 9.2;Pp 109-116.

[32] Subhan Amhad and Arshad Umar. 2017. Characterisation of self-compacting

concrete. International symposium of plastic and impact mechanics;IMPAST 2016.(www.Elsevier.com)https://www.sciencedirect.com/science/journal/22150986. 